\title{
APPLICATION OF COOPERATIVE LEARNING MODEL TYPE THINK PAIR SHARE (TPS) ON MATHEMATICAL COMMUNICATION ABILITY
}

\author{
Andi Mulawakkan Firdaus ${ }^{1)}$ \\ ${ }^{1}$ Pendidikan Matematika, Universitas Muhammadiyah Makassar \\ *E-mail : andi.mulawakkan@unismuh.ac.id
}

\begin{abstract}
This research is a quasi-experimental study which aims to describe the effect of cooperative learning type Think Pair Share (TPS) on students' mathematical communication skills, and to find out the percentage of students' activeness in participating in learning and knowing students' positive responses to learning. The output that will be generated in this study is that students can be more active in the learning process, more active in solving mathematical problems, and can be more confident in expressing their answers in public so that after applying cooperative learning models the Think Pair Share (TPS) mathematical communication skills of students will be better. The research subjects were divided into 2 groups, namely the experimental group taught using the cooperative learning model Think Pair Share (TPS) type, and the control group taught using Conventional learning models. Each group is taught with the same frequency of meetings with the same material. The results of the study show that the application of the cooperative learning model Think Pair Share (TPS) influences students' mathematical communication skills.
\end{abstract}

Keywords : Mathematical Communication; Conventional; Think Pair Share (TPS)

\section{PENDAHULUAN}

Matematika merupakan salah satu mata pelajaran yang diajarkan pada setiap jenis dan jenjang pendidikan, baik pendidikan umum maupun pendidikan kejuruan, mulai dari pendidikan dasar sampai perguruan tinggi (Muzaini, 2016). Matematika juga merupakan bahasa simbol dimana setiap orang yang belajar matematika dituntut untuk mempunyai kemampuan untuk berkomunikasi dengan menggunakan bahasa simbol tersebut (Noerazizah, 2011). Baird (Hendriana, 2017) menyatakan bahwa komunikasi dapat diartikan sebagai suatu proses penyampaian dan penerimaan hasil pemikiran individu melalui symbol kepada orang lain. Kemampuan siswa dalam berkomunikasi sangat berperan penting dalam proses pembelajaran karena dengan berkomunikasi proses pembelajaran akan berjalan dengan sempurna dan mudah untuk dimengerti.

Kemampuan komunikasi dalam pembelajaran matematika (mathematical communication) sangat perlu untuk dikembangkan. Hal ini karena melalui kemampuan komunikasi matematika, siswa dapat mengorganisasikan kemampuan berpikir matematikanya baik secara lisan maupun tulisan. Siswa yang sudah mempunyai pemahaman matematik dituntut untuk dapat mengkomunikasikannya agar pemahaman tersebut bisa dimengerti oleh orang lain. Sumarno (Hendriana, 2017) kemampuan komunikasi matematis siswa dapat dilihat dalam beberapa kegiatan matematis, yaitu 1) menghubungkan benda nyata, gambar, dan diagram 
kedalam ide matematika. 2) menjelaskan ide, situasi, dan relasi matematika secara lisan atau tulisan, dengan benda nyata, gambar, grafik, dan aljabar. 3) menyatakan peristiwa sehari-hari dalam bahasa matematika. 4) mendengarkan, diskusi, dan menulis tentang matematika. 5) membaca dengan pemahaman suatu presentasi matematika tertulis. 6) menyusun pertanyaan matematika yang relevan dengan situasi masalah. 7) membuat konjektur, menyusun argument, merumuskan definisi dan generalisasi.

Berdasarkan observasi yang dilakukan oleh peneliti di kelas XI SMK Muhammadiyah 3 Cabang Makassar, menunjukkan bahwa siswa kurang aktif dalam proses pembelajaran seperti kurangnya kepercayaan diri siswa dalam mengungkapkan jawaban dari soal yang diberikan oleh gurunya, siswa hanya ingin menjawab apabila ditunjuk langsung oleh gurunya, dan masih banyak siswa yang malu untuk bertanya kepada gurunya ketika ada materi yang kurang dipahami. Untuk itu faktor utama penyebab kurangnya kemampuan komunikasi belajar matematika diantaranya terdapat pada metode pembelajaran yang digunakan oleh guru yang kurang bervariasi serta kurang maksimalnya guru dalam proses pembelajaran, untuk itu aktivitas peserta didik perlu ditingkatkan melalui latihan-latihan atau tugas matematika dengan bekerja kelompok kecil dan menjelaskan ide-ide kepada orang lain.

Salah satu alternatif untuk memecahkan masalah tersebut adalah dengan melalui model pembelajaran kooperatif tipe Think Pair Share (TPS). Karlina (2009) menyatakan bahwa sistem pembelajaran kooperatif atau cooperative learning merupakan sistem pengajaran yang memberi kesempatan kepada anak didik untuk bekerja sama dengan sesama siswa dalam tugas-tugas yang terstruktur. Laksmi (2014) mengemukakan bahwa model pembelajaran kooperatif tipe Think Pair Share (TPS) memungkinkan siswa untuk bekerja sendiri dan bekerja sama dengan orang lain sehingga mengoptimalkan partisipasi siswa. Selain itu model ini juga memberikan siswa waktu lebih banyak untuk berpikir, menjawab dan saling membantu satu sama lain. Adapun model pembelajaran kooperatif Think Pair Share (TPS) yaitu dalam bahasa Indonesia, Think artinya berfikir, Pair artinya berpasangan, dan Share artinya berbagi. Jadi, Think Pair Share (TPS) adalah model pembelajaran yang memungkinkan siswa untuk bekerjasama dalam kelompok-kelompok kecil dengan tahap thinking (berpikir), pairing (berpasangan), dan sharing (berbagi).Dalam model pembelajara ini siswa dapat lebih aktif dalam proses pembelajaran, lebih aktif dalam menyelesaikan masalah matematika, dan dapat lebih percaya diri dalam mengungkapkan jawabannya didepan umum.

Berdasarkan penelitian yang dilakukan Vitriani (2014) terhadap siswa kelas VIII SMPN 13 Padang yang menggunakan Metode Think Pair Share (TPS) untuk mengetahui kemampuan komunikasi matematika siswa menunjukkan bahwa pembelajaran dengan menggunakan model pembelajaran kooperatif tipe Think Pair Share lebih baik dibandingkan dengan pembelajaran konvensionl. Penelitian yang dilakukan oleh Hafni (2017) terhadap siswa kelas VII MTs AlIshlahiyah Binjai yang menggunakan metode Think Pair Share (TPS) untuk mengetahui kemampuan komunikasi matematika siswa, menunjukkan bahwa 
komunikasi matematika siswa meningkat dengan menerapkan model pembelajaran kooperatif tipe Think-Pair-Share (TPS).

Dari uraian diatas, penelitian ini bertujuan untuk mengetahui apakah model pembelajaran kooperatif tipe Think Pair Share (TPS) berpengaruh terhadap kemampuan komunikasi matematika siswa, juga untuk mengetahui sebarapa besar persentasi keaktifan siswa dalam mengikuti pembelajaran dan bagaimana respon siswa yang positif terhadap pembelajaran.

\section{METODE PENELITIAN}

Penelitian ini merupakan jenis penelitian eksperimen, yaitu metode penelitian yang digunakan untuk mencari pengaruh perlakuan tertentu terhadap yang lain dalam kondisi yang terkendalikan (Firdaus, 2016). Dalam penelitian ini melibatkan 2 kelompok, yaitu satu kelompok sebagai kelompok eksperimen (percobaan) dan satu kelompok sebagai kelompok kontrol (pembanding). Untuk kelompok eksperimen diajar dengan menggunakan model pembelajaran kooperatif tipe Think Pair Share (TPS) sedangkan pada kelompok kontrol diajar dengan menggunakan model pembelajaran konvensional. Adapun populasi dari penelitian ini adalah seluruh siswa kelas XI SMK Muhammadiyah 3 Cabang Makassar pada semester genap tahun ajaran 2018/2019. Sampel dari penelitian ini terdiri dari dua kelas yang berjumlah 20 orang.

Jenis pengambilan sampel yang digunakan dalam penelitian ini adalah teknik Cluster Random Sampling, yaitu teknik pengambilan sampel dimana pemilihan mengacu pada kelompok bukan pada individu (Sugiyono, 2010). Pada penelitian ini peneliti mengambil 2 kelas secara acak sebagai sampel yaitu kelas XI TKJ sebagai kelas eksperimen yang menerapkan model pembelajaran kooperatif tipe Think Pair Share (TPS) dan kelas XI Akuntansi sebagai kelas control yang menerapkan model pembelajaran konvensional pada pembelajaran matematika.

Setelah menetapkan subjek penelitian, maka pelaksanaan penelitian dilaksanakan sebagai berikut:

1. Pelaksanaan penelitian berlangsung selama 4 kali pertemuan

2. Menetapkan masing-masing kelas yang menjadi subjek penelitian yakni kelompok eksperimen yang diajar dengan menggunakan pembelajaran kooperatif tipe sebagai kelas eksperimen yang menerapkan model pembelajaran kooperatif tipe Think Pair Share (TPS) dan kelompok kontrol yang diajar dengan menggunakan model pembelajaran konvensional.

3. Setiap kelompok diajar dengan frekuensi pertemuan dan materi yang sama

4. Pada akhir pembelajaran diberikan tes dengan bobot soal yang sama.

Instrumen penelitian yang akan digunakan adalah tes kemampuan komunikasi matematika siswa, Lembar Observasi Aktivitas Siswa selama proses pembelajaran, dan Angket Respon Siswa. Untuk menganalisis data yang diperoleh adalah dengan menggunakan analisis statistika deskriptif dan analisis statistika inferensial. 
Pengumpulan data untuk komunikasi matematika siswa, dikumpulkan dengan menggunakan metode tes. Tes diberikan sebelum dan setelah diberi perlakuan (pretest-posttest), pada kelas eksperimen dan kelas control baik soalsoal untuk pretest dan posttest adalah soal yang sama. Metode observasi menggunakan lembar pengamatan keterampilan aktivitas siswa untuk mengamati kegiatan siswa selamaproses pembelajaran dengan menggunakan model pembelajaran kooperatif tipe Think Pair Share (TPS).

Teknik yang digunakan untuk memperoleh data respon siswa adalah dengan membagikan angket kepada siswa setelah berakhirnya pertemuan terakhir untuk diisi sesuai dengan petunjuk yang diberikan.Teknik analisis data yang digunakan untuk menganalisis data yang diperoleh adalah dengan menggunakan analisis statistika deskriptif dan analisis statistika inferensial. Jenis data tes kemampuan komunikasi matematika siswasetelah kedua sampel diberi perlakuan yang berbeda, maka data yang diperoleh dari tes kemampuan awal dan tes kemampuan akhir dianalisis untuk mendapatkan skor peningkatan (gain) pada kedua kelas.Analisis ini bertujuan untuk mengetahui peningkatan kemampuan komunikasi matematis siswa pada kelas eksperimen dan kelas konvensional, yang selanjutnya diinterpretasikan dengan menggunakan Kriteria Indeks Gain (Husna, 2013).

Tabel 1 Kriteria Indeks Gain

\begin{tabular}{ccc}
\hline No. & Indeks Gain $(\mathbf{g})$ & Kriteria \\
\hline 1. & $\mathrm{~g} \geq 0,70$ & Tinggi \\
\hline 2. & $0,30 \leq \mathrm{g}<0,70$ & Sedang \\
\hline 3. & $\mathrm{~g}<0,30$ & Rendah \\
\hline
\end{tabular}

Kemudian kriteria yang digunakan untuk menentukan kategori dari skor kemampuan komunikasi matematika pada penelitian ini yaitu berdasarkan teknik kategori standar yang ditetapkan oleh Departemen Pendidikan dan kebudayaan (Firdaus, 2016), sebagai berikut.

Tabel 2.Kriteria Pengkategorian Komunikasi Matematika

\begin{tabular}{ccc}
\hline No. & Skor & Predikat \\
\hline 1. & $81-100$ & Sangat tinggi \\
\hline 2. & $71-80$ & Tinggi \\
\hline 3. & $61-70$ & Sedang \\
\hline 4. & $51-60$ & Rendah \\
\hline 5. & $0-50$ & Sangat rendah \\
\hline
\end{tabular}

Statistik inferensial adalah teknik statistik yang digunakan untuk menganalisis data sampel dan hasilnya diberlakukan untuk populasi.Teknik statistik ini dimaksudkan untuk menguji hipotesis penelitian.Sebelum menguji hipotesis penelitian, dilakukan uji normalitas dan uji homogenitas.

\section{Uji Normalitas}

Uji normalitas digunakan untuk mengetahui apakah distribusi data yang didapat berasal dari populasi yang berdistribusi normal atau tidak. Uji Normalitas dalam penelitian ini menggunakan uji One Sample Kolmogorov-Smirnov dengan menggunakan tarif signifikan $5 \%$ atau 0,05 , dengan syarat yaitu:

Jika $P_{\text {value }}<0,05$ maka $\mathrm{H}_{0}$ ditolak dan $\mathrm{H}_{1}$ diterima 
Jika $\boldsymbol{P}_{\text {value }} \geq 0,05$ maka $\mathrm{H}_{0}$ diterima dan $\mathrm{H}_{1}$ ditolak

\section{Uji Homogenitas}

Uji homogenitas dilakukan untuk menyelidiki variansi kedua sampel sama atau tidak. Uji yang digunakan adalah uji Levene's Tes for Equality of Variances. Uji ini dilakukan sebagai prasyarat dalam analisis $t$-Test. Jika sampel tersebut memiliki varians yang sama, maka keduanya dikatakan homogeny, pada L evene's Tes for Equality of Variances digunakan taraf signifikansi 5\% atau 0,05, Furqan (2008) dengan syarat :

Jika $P_{\text {value }}<0,05$ maka $\mathrm{H}_{0}$ ditolak dan $\mathrm{H}_{1}$ diterima

Jika $P_{\text {value }} \geq 0,05$ maka $\mathrm{H}_{0}$ diterima dan $\mathrm{H}_{1}$ ditolak

Adapun langkah-langkah dalam uji homogenitas adalah sebagai berikut:

a. Menentukan apakah kedua varian (kelompok eksperimen dan kelompok kontrol) adalah homogen atau tidak.

b. Kriteria pengujian (berdasarkan probabilitas/signifikansi)

Jika $P_{\text {value }} \geq 0,05$ maka kedua varian sama

Jika $P_{\text {value }}<0,05$ maka kedua varian berbeda

c. Membandingkan probabilitas

Nilai $P_{\text {value }} \geq 0,05$ maka kedua varian adalah sama

d. Menarik kesimpulan Untuk menguji hipotesis nol, bahwa rata-rata dua kelompok tidak berbeda maka digunakan t-Test. Namun pada dasarnya keduanya akan menghasilkan kesimpulan yang sama, yaitu menerima atau menolak hipotesis nol. Pada penelitian ini dirumuskan hipotesis sebagai berikut:

Ho $=$ Skor rata-rata kemampuan komunikasi matematika siswa kelas XI SMK Muhammadiyah 3 Cabang Makassar untuk model pembelajaran kooperatif tipe Think Pair Share (TPS) dan pembelajaran konvensional sama saja.

$\mathrm{H}_{1}=$ Skor rata-rata kemampuan komunikasi matematika siswa kelas XI SMK Muhammadiyah 3 Cabang Makassar untuk model pembelajaran kooperatif tipe Think Pair Share (TPS) lebih baik daripada pembelajaran konvensional.

\section{HASIL PENELITIAN DAN PEMBAHASAN}

\section{Kelas Eksperimen}

Hasil statistik skor kemampuan komunikasi matematika pada siswa kelas XI TKJ sebelum diberi perlakuan (Pretest) dan setelah diberi perlakuan (Postest) yang diajar dengan model pembelajaran kooperatif Tipe Think-Pair-Share (TPS).

Tabel 3. Deskripsi Skor Kemampuan Komunikasi Matematis Sebelum dan Setelah diterapkan Model Kooperatif Tipe Think-Pair-Share (TPS)

\begin{tabular}{lcc}
\hline \multirow{2}{*}{ Statistik } & \multicolumn{2}{c}{ Nilai Statistik } \\
\cline { 2 - 3 } & Pretest & Posttest \\
\hline Ukuran Sampel & 20 & 20 \\
Skor Ideal & 100 & 100 \\
\hline
\end{tabular}




\begin{tabular}{lcc}
\hline Skor Maksimum & 42 & 90 \\
Skor Minimum & 26 & 60 \\
Rentang Skor & 16 & 36 \\
Skor Rata-rata & 31,90 & 79,30 \\
Standar Deviasi & 3,81 & 8,44 \\
Variansi & 14,51 & 71,33 \\
\hline
\end{tabular}

Berdasarkan Tabel 3. menunjukkan bahwa skor rata-rata kemampuan komunikasi matematika siswa pada pokok bahasan Matriks sebelum diberi perlakuan (Pretest) adalah 31,90 dari skor ideal 100 yang mungkin dicapai oleh siswa, sedangkan skor rata-rata kemampuan komunikasi matematika siswa setelah diberi perlakuan (Postest) adalah 79,30 dari skor ideal 100 yang mungkin dicapai oleh siswa. Hal ini menunjukkan bahwa pada kelas XI SMK Muhammadiyah 3 Cabang Makassar dengan menggunakan model kooperatif tipe Think-Pair-Share (TPS) terjadi peningkatan sebesar 47,4.

Jika skor kemampuan komunikasi matematika siswa sebelum dan setelah pembelajaran dengan menerapkan model kooperatif tipe Think-Pair-Share (TPS) dikelompokkan kedalam lima kategori maka diperoleh tabel distribusi frekuensi dan persentase.

Tabel 4. Distribusi Frekuensi dan Persentase Skor Kemampuan Komunikasi Matematika Sebelum diterapkan Model Kooperatif Tipe Think-Pair-Share (TPS)

\begin{tabular}{ccccc}
\hline No. & Skor & Kategori & Frekuensi & Persentase (\%) \\
\hline 1. & $81-100$ & Sangat tinggi & 0 & 0 \\
\hline 2. & $71-80$ & Tinggi & 0 & 0 \\
\hline 3. & $61-70$ & Sedang & 0 & 0 \\
\hline 4. & $51-60$ & Rendah & 0 & 0 \\
\hline 5. & $0-50$ & Sangat rendah & 20 & 100 \\
\hline \multicolumn{7}{r}{ Jumlah } & $\mathbf{2 0}$ & $\mathbf{1 0 0}$ \\
\hline
\end{tabular}

Tabel 5. Distribusi Frekuensi dan Persentase Skor Kemampuan Komunikasi Matematika Setelah diterapkan Model Kooperatif Tipe Think-Pair-Share (TPS)

\begin{tabular}{ccccc}
\hline No. & Skor & Kategori & Frekuensi & Persentase (\%) \\
\hline 1. & $81-100$ & Sangat tinggi & 9 & 45 \\
\hline 2. & $71-80$ & Tinggi & 8 & 40 \\
\hline 3. & $61-70$ & Sedang & 2 & 10 \\
\hline 4. & $51-60$ & Rendah & 1 & 5 \\
\hline 5. & $0-50$ & Sangat rendah & 0 & 0 \\
\hline \multicolumn{7}{c}{ Jumlah } & $\mathbf{2 0}$ & $\mathbf{1 0 0}$ \\
\hline
\end{tabular}

Berdasarkan Tabel 4 menunjukkan bahwa dari 20 peserta didik kelas XI SMK Muhammadiyah 3 Cabang Makassar yang mengikuti pretest terdapat 20 peserta didik atau $100 \%$ peserta didik termasuk dalam kategori sangat rendah. Sedangkan, pada Tabel 5 menunjukkan bahwa dari 20 peserta didik kelas XI SMK Muhammadiyah 3 Cabang Makassar yang mengikuti Postest terdapat lima 
kategori yakni pada kategori sangat rendah tidak terdapat siswa yang berada pada kategori tersebut atau $0 \%$, pada kategori rendah hanya ada 1 orang atau sekitar $5 \%$, pada kategori sedang ada 2 orang atau sekitar $10 \%$, pada kategori tinggi ada 8 orang atau sekitar $40 \%$ dan pada kategori sangat tinggi terdapat 9 peserta didik atau sekitar $45 \%$ yang termasuk dalam kategori tersebut.

\section{Kelas Kontrol}

Hasil statistik skor kemampuan komunikasi matematika pada siswa kelas XI Akuntansi sebelum diberi perlakuan (Pretest) dan setelah diberi perlakuan (Postest) yang diajar dengan model pembelajaran Konvensional.

Tabel 6. Statistik Skor Kemampuan Komunikasi Matematis Sebelum dan Setelah diterapkan Model Pembelajaran Konvensional

\begin{tabular}{lcc}
\hline \multirow{2}{*}{ Statistik } & \multicolumn{2}{c}{ Nilai Statistik } \\
\cline { 2 - 3 } & Pretest & Posttest \\
\hline Ukuran Sampel & 20 & 20 \\
Skor Ideal & 100 & 100 \\
Skor Maksimum & 47 & 75 \\
Skor Minimum & 30 & 40 \\
Rentang Skor & 17 & 35 \\
Skor Rata-rata & 37,95 & 54,8 \\
Standar Deviasi & 4,18 & 8,78 \\
Variansi & 17,52 & 77,11 \\
\hline Berdasarkan
\end{tabular}

Berdasarkan Tabel 6. menunjukkan bahwa skor rata-rata kemampuan komunikasi matematika siswa pada pokok bahasan Matriks sebelum diberi perlakuan (Pretest) adalah 37,95 dari skor ideal 100 yang mungkin dicapai oleh siswa, sedangkan skor rata-rata kemampuan komunikasi matematika siswa setelah diberi perlakuan (Postest) adalah 54,8 dari skor ideal 100 yang mungkin dicapai oleh siswa. Hal ini menunjukkan bahwa pada kelas XI SMK Muhammadiyah 3 Cabang Makassar dengan menggunakan model pembelajaran konvensional terjadi peningkatan sebesar 16,85 .

Selanjutnya jika skor kemampuan komunikasi matematika siswa sebelum dan setelah diterapkan model pembelajaran konvensional dikelompokkan kedalam lima kategori maka diperoleh tabel distribusi frekuensi dan persentase.

Tabel 7. Distribusi Frekuensi dan Persentase Skor Kemampuan Komunikasi

Matematika Sebelum diterapkan Model Pembelajaran Konvensional

(Pretest)

\begin{tabular}{ccccc}
\hline No. & Skor & Kategori & Frekuensi & Persentase (\%) \\
\hline 1. & $81-100$ & Sangat tinggi & 0 & 0 \\
\hline 2. & $71-80$ & Tinggi & 0 & 0 \\
\hline 3. & $61-70$ & Sedang & 0 & 0 \\
\hline 4. & $51-60$ & Rendah & 0 & 0 \\
\hline 5. & $0-50$ & Sangat rendah & 20 & 100 \\
\hline \multicolumn{7}{r}{ Jumlah } & $\mathbf{2 0}$ & $\mathbf{1 0 0}$ \\
\hline
\end{tabular}


Tabel 8. Distribusi Frekuensi dan Persentase Skor Kemampuan Komunikasi Matematika Setelah diterapkan Model Pembelajaran Konvensional (Postest)

\begin{tabular}{|c|c|c|c|c|}
\hline No. & Skor & Kategori & Frekuensi & Persentase (\%) \\
\hline 1. & $81-100$ & Sangat tinggi & 0 & 0 \\
\hline 2. & $71-80$ & Tinggi & 1 & 5 \\
\hline 3. & $61-70$ & Sedang & 2 & 10 \\
\hline 4. & $51-60$ & Rendah & 10 & 50 \\
\hline 5. & $0-50$ & Sangat rendah & 7 & 35 \\
\hline \multicolumn{3}{|c|}{ Jumlah } & 20 & 100 \\
\hline
\end{tabular}

Berdasarkan Tabel 7 menunjukkan bahwa dari 20 peserta didik kelas XI SMK Muhammadiyah 3 Cabang Makassar yang mengikuti pretest terdapat 20 peserta didik atau $100 \%$ peserta didik termasuk dalam kategori sangat rendah. Sedangkan, pada Tabel 8 menunjukkan bahwa dari 20 peserta didik kelas XI SMK Muhammadiyah 3 Cabang Makassar yang mengikuti Postest terdapat lima kategori yakni pada kategori sangat rendah ada 7 orang atau sekitar $35 \%$, pada kategori rendah ada 10 orang atau sekitar $50 \%$, pada kategori sedang ada 2 orang atau sekitar $10 \%$, pada kategori tinggi ada 1 orang atau sekitar $5 \%$ dan pada kategori sangat tinggi tidak terdapat peserta didik yang termasuk dalam kategori tersebut.

Untuk melihat persentase peningkatan (N-gain) kemampuan komunikasi matematika siswa pada kelas eksperimen dan kelas control dapat dilihat pada tabel berikut.

Tabel 9. Hasil Uji Peningkatan (N-gain) Kemampuan Komunikasi Matematika

\begin{tabular}{|l|c|c|}
\hline Kelas & $\begin{array}{c}\text { Kelas XI TKJ } \\
\text { (Kelas Eksperimen) }\end{array}$ & $\begin{array}{c}\text { Kelas XI Akuntansi } \\
\text { (Kelas Kontrol) }\end{array}$ \\
\hline$S_{\text {Pretest }}$ & 36,05 & 37,95 \\
\hline$S_{\text {Postest }}$ & 72,55 & 54,8 \\
\hline Gain & 0,57 & 0,27 \\
\hline Keterangan & Sedang & Rendah \\
\hline
\end{tabular}

Berdasarkan data tersebut, hasil perhitungan gain pada kelas eksperimen (kelas TKJ) diperoleh rata-rata pretest sebesar 36,05 dan rata-rata posttest sebesar 72,55. Sehingga diperoleh gain sebesar 0,57 artinya bahwa kelas eksperimen (kelas TKJ) mengalamai peningkatan kemampuan komunikasi matematika dengan kategori sedang karena indeks gain $0,30 \leq \mathrm{g}<0,70$. Pada kelas kontrol (kelas Akuntansi) diperoleh rata-rata pretest sebesar 37,95 dan rata-rata posttest sebesar 54,8. Sehingga diperoleh gain sebesar 0,27 artinya bahwa kelas kontrol (kelas Akuntansi) mengalamai peningkatan kemampuan komunikasi matematika, namun peningkatannya dalam kategori rendah karena indeks gain $\mathrm{g}<0,30$.

Dari pembahasan diatas, dapat ditarik kesimpulan bahwakelas XI SMK Muhammadiyah 3 Cabang Makassar khususnya materi Matriks dengan model pembelajaran kooperatif tipe Think Pair Share (TPS) dapat berpengaruh terhadap kemampuan komunikasi matematika siswa. Berdasarkan hasil penelitian, 
menunjukkan bahwa model pembelajaran kooperatif tipe Think Pair Share (TPS) dapat meningkatkan hasil belajar matematika siswa.

Hasil analisis deskriptif menunjukkan bahwa Hasil analisis data kemampuan komunikasi matematika siswa pada kelas eksperimen atau pembelajaran yang menerapkan model kooperatif tipe Think Pair Share (TPS) menunjukkan bahwa skor rata-rata kemampuan komunikasi matematika siswa pada pokok bahasan Matriks sebelum diberi perlakuan (Pretest) adalah sebesar 31,90 (kategori sangat rendah) dan skor rata-rata kemampuan komunikasi matematika siswa setelah diberi perlakuan (Postest) adalah sebesar 79,30 (kategori tinggi). Sedangkan pada kelas control atau pembelajaran yang menerapkan model konvensional menunjukkan bahwa skor rata-rata kemampuan komunikasi matematika siswa sebelum diberi perlakuan (Pretest) adalah sebesar 37,95 (kategori sangat rendah) dan skor rata-rata kemampuan komunikasi matematika siswa setelah diberi perlakuan (Postest) adalah sebesar 54,8 (kategori rendah). Sehingga dapat dikatakan bahwa pada kelas XI SMK Muhammadiyah 3 Cabang Makassar dalam proses pembelajaran matematika dengan menerapkan model kooperatif tipe Think Pair Share (TPS) berpengaruh terhadap kemampuan komunikasi matematika siswa.

Hasil analisis inferensial menunjukkan bahwa skor rata-rata kemampuan komunikasi matematika siswa setelah pembelajaran matematika melalui penerapan model kooperatif tipe Think Pair Share (TPS) tampak Nilai p (sig.(2tailed)) adalah $0,000<0,05$ yang artinya $\mathrm{H}_{0}$ ditolak dan $\mathrm{H}_{1}$ diterima yang berarti bahwa skor rata-rata kemampuan komunikasi matematika siswa kelas XI SMK Muhammadiyah 3 Cabang Makassar untuk model pembelajaran kooperatif tipe Think Pair Share (TPS) lebih baik daripada model pembelajaran konvensional.

Berdasarkan hasil pengamatan aktivitas siswa pada kelas eksperimen yang menerapkan model pembelajaran kooperatif tipe Think Pair Share (TPS) menunjukkan siswa aktif lbih dalam proses pembelajaran dibandingkan dengan kelas control yang menerapkan model pembelajaran konvensional, terlihat dari rata-rata persentase aktivitas positif siswa pada kelas eksperimen sebesar 71,07\% sedangkan pada kelas control hanya sebesar 58,21\%. Selain itu, siswa lebih memilih belajar dengan menerapkan model pembelajaran kooperatif tipe Think Pair Share (TPS) daripada model pembelajaran konvensional.

\section{SIMPULAN DAN SARAN}

\section{Simpulan}

Berdasarkan hasil penelitian dan pembahasan, maka kesimpulan dari peneilitian ini yaitu terdapat pengaruh dari penerapan model kooperatif tipe Think Pair Share (TPS) terhadap kemampuan komunikasi matematika siswa kelas XI SMK Muhammadiyah 3 Cabang Makassar. Siswa lebih aktif dalam proses pembelajaran yang menerapkan model kooperatif tipe Think-Pair-Share (TPS) daripada model pembelajaran konvensional. Respon siswa yang positif terhadap pembelajaran yang menerapkan model kooperatif tipe Think Pair Share (TPS) sangat baik. 


\section{Saran}

Berdasarkan hasil penelitian ini, peneliti memberikan saran yaitu disarankan kepada peneliti lain yang akan menindaklanjuti penelitian ini untuk menyempurnakan atau paling tidak mengurangi kelemahan-kelemahan dalam penelitian agar hasil yang diperoleh lebih akurat.

\section{DAFTAR PUSTAKA}

Firdaus, A. M. (2016). Efektivitas pembelajaran matematika melalui penerapan model pembelajaran kooperatif tipe snowball throwing. Beta Jurnal Tadris Matematika, 9(1), 61-74.

Furqan. (2008). Statistik Terapan untuk Penelitian. Bandung. Alfabeta.

Hendriana, dkk (2017) Hard Skills dan Soft Skills Matematika Siswa. Bandung: PT Refika Aditama.

Husna, M., \& Fatimah, S. (2013). Peningkatan kemampuan pemecahan masalah dan Komunikasi matematis siswa Sekolah Menengah Pertama melalui model pembelajaran kooperatif tipe Think-pair-share (TPS). Jurnal Peluang, 1(2), 81-92.

Hafni, M. (2016).Meningkatkan Kemampuan Komunikasi Matematika Pada Materi Bilangan Bulat Dengan Model Kooperatif Think-Pair-Share Pada Siswa Kelas Vii Di Mts. Al-Ishlahiyah Binjai Ta 2016/2017 (Doctoral Dissertation, Unimed).

Karlina, I. (2009). Pembelajaran kooperatif (cooperative learning) sebagai salah satu strategi membangun pengetahuan siswa.

Laksmi, N. (2014). Pengaruh Penerapan Model Pembelajaran Kooperatif Tipe Think Pair Share Terhadap Kemampuan Komunikasi Matematis Siswa (Studi Pada Siswa Kelas VIII Smp Negeri 1 Baradatu Semester Genap Tahun Pelajaran 2013/2014).

Muzaini, M. (2016). Pengaruh pendekatan problem posing terhadap prestasi belajar matematika siswa berdasarkan gaya kognitif. Beta Jurnal Tadris Matematika, 9(2), 161-179.

Noerazizah, S. M. (2011). Pengaruh Penerapan Model Pembelajaran Kooperatif Tipe Think Pair Share (TPS) Terhadap Kemampuan Komunikasi Matematis Siswa (Kuasa Eksperimen Di SMPN 3 Tangerang Selatan).

Sugiyono. (2010). Metode Penelitian Kuantitatif, Kualitatif, dan $R \&$ D. Bandung: Alfabeta.

Vitriani, J. (2014). Pengaruh Penerapan Model Pembelajaran Kooperatif Tipe Think Pair Share (TPS) Terhadap Kemampuan Komunikasi Matematika Siswa. Jurnal Pendidikan Matematika, 3(1). 